STUDIA SPORTIVA 2013 / č. 3, s. 267-278

\title{
Srovnání alternativních pohybových aktivit a her u osob se specifickými nároky v ČR a zahraničí
}

\section{Comparison of Alternative Physical Activities and Games in People with Special Needs in the Czech Republic and Abroad}

\author{
Dagmar Trávníková \\ Fakulta sportovních studií, Masarykova univerzita, Brno, \\ Česká republika
}

\section{Abstrakt:}

Př́spěvek predstavuje různé prístupy v oblasti alternativních pohybových aktivit osob se specifickými nároky na základè spolupráce Fakulty sportovnich studií a dalších institucízabývajících se touto problematikou. V rámci projektu CZ.1.07/2.4.00/17.0037 probihaji krátkodobé stáže, semináre a konzultace akademiků a studenti̊ FSpS a spolupracujicich institucí, jejichž hlavním cílem je srovnání pojetí pohybových aktivit u různých typư postižení či specifických nárokủ a jejich následné uvedení do praxe na jednotlivých institucích. Akademici a studenti tak maji možnost načerpat nové zkušenosti a dovednosti z nejrůznějšich oblastí alternativnich pohybových aktivit jako jsou napr. dramatické aktivity u Neslyšicich, Halliwickova metoda plavání, žonglérské a psychomotorické hry, psychomotorická terapie, využivání kompenzačních pomi̊cek, aj.

\section{Abstract:}

The paper presents various approaches in the field of alternative physical activities in people with special needs based on cooperation of the Faculty of Sports Studies and other institutions dealing with this topic. Within the CZ.1.07/2.4.00/17.0037 project various short-term stays, se- 
minars and consultations between academics and students of the FSpS and the cooperating institutions take place, the main goal of which is to compare the concepts of physical activities in different types of handicaps or special needs and their subsequent introduction into practice in the particular institutions. Both academics and students thus have opportunity to gain new experience and skills from various fields of alternative physical activities such as dramatic activities in the Deaf, Halliwick swimming concept, juggling and psychomotor games, psychomotor therapy, use of compensation tools etc.

Klíčová slova: alternativní pohybové aktivity a hry, psychomotorika, žonglování, Halliwickova metoda plavání, osoby se specifickými nároky.

Key words: alternative physical activities and games, psychomotricity, juggling, Halliwick swimming concept, people with special needs.

Výše zminěné aktivity byly uskutečněny v rámci projektu Rozvoj v oblasti pedagogicko-výzkumných aktivit na katedře společenských věd ve sportu na FSpS MU, CZ.1.07/2.4.00/17.0037.

\section{ÚVOD}

V souvislosti se současným trendem integrace žáků a studentů se specifickými nároky do běžných škol a vzdělávacích institucí vyvíjí Masarykova univerzita $v$ Brně snahy pokrýt nabídku vzdělávání těchto studentů ve všech oblastech, včetně sportovně-pohybových aktivit. Ty probíhají pod hlavičkou celouniverzitní tělesné výchovy v podobě pravidelných týdenních setkání či několikadenních kurzů. Asistenci a podporu studentům Masarykovy univerzity se specifickými nároky zajišt'uje středisko Teiresiás. Vybraní lektoři z Fakulty sportovních studií (dále jen FSpS) se spolupodílejí na výuce a inovaci nabídky těchto specifických předmětů. Nově tak vznikl např́klad předmět Alternativní pohybové aktivity a hry, při němž mají studenti se zrakovým, sluchovým či tě- 
lesným postižením možnost vyzkoušet si netradiční pohybové aktivity jako žonglování, rytmické a divadelní aktivity, psychomotorické hry nebo nové kompenzační pomůcky.

Název nově vzniknuvšího předmětu odráží fakt, že vyučované aktivity a v nich využívané pomůcky jsou svým charakterem inovativní a netradiční a nejedná se tedy o aktivity primárně ,aplikované“ a význačně určené pro osoby s postižením či jinými specifickými nároky. Pohybových lekcí se účastní studenti s postižením, studenti speciální pedagogiky i např. výkonnostně sportovně zaměření studenti Fakulty sportovních studií. Tato vzájemná interakce dodává předmětu významný sociální rozměr.

Podle Válkové (2012) se terminologie související s aplikovanými pohybovými aktivitami od 80 . let minulého století neustále vyvíjí a také Mezinárodní federace aplikovaných pohybových aktivit chápe „APA“ jako termín mnoha významů, který však zdůrazňuje individuální rozdíly v pohybových aktivitách, přičemž adaptace znamená nutnost modifikace, přizpưsobení či úpravu v souladu s individuálními potřebami cílové skupiny. Válková však shrnuje, že všechny definice spojují společné rysy, jako jsou multidisciplinární př́stup, snaha o zvýšení kvality života osob z minoritních skupin a adaptaci podmínek nebo prostředí.

Tento př́spěvek je výstupem projektu s názvem ,Rozvoj $v$ oblasti pedagogicko-výzkumných aktivit na Katedře společenských věd ve sportu na FSpS MU“, CZ.1.07/2.4.00/17.0037, podpořeného Evropským sociálním fondem a státním rozpočtem České republiky.

V rámci výše zmíněného projektu navázal řešitelský tým FSpS spolupráci s několika českými a zahraničními institucemi terciárního vzdělávání, které se rovněž zabývají aplikovanými či netradičními pohybovými aktivitami a jejich implementací do oblasti sportu a pohybových aktivit osob s postižením či jinými specifickými nároky. Díky tomu mají akademici i studenti FSpS možnost načerpat nové inspirace z této progresivní oblasti a sdílet zkušenosti a znalosti o specificích jednotlivých postižení. Spolupráce je realizována formou stáží, konzultací a seminářò, jejichž výstupy poté akademici z FSpS využívají při samotné výuce 
nebo při pohybových lekcích s cílovými skupinami (např̀. klienti s tělesným postižením Kociánky Brno, senioři s Parkinsonovou chorobou, aj).

Cílem tohoto příspěvku je představit výsledky spolupráce řešitelského týmu Fakulty sportovních studií a specifika př́istupů spolupracujících českých i zahraničních institucí k oblasti aplikovaných a alternativních pohybových aktivit.

\section{Aplikované pohybové aktivity na Fakultě sportovních studií Masarykovy univerzity}

Jak již bylo naznačeno $\mathrm{v}$ úvodu, Masarykova univerzita (dále jen MU) nabízí svým studentům s postižením podporu nejen v rámci jejich studijního zaměření, ale také z hlediska pohybového a sportovního vyžití. „Podpora studentům“ je realizována především jako asistence na jednotlivých lekcích, tlumočení do znakového jazyka či nabídka doprovodu studenta do místa výuky. Pohybové aktivity v rámci celouniverzitní tělesné výchovy pro studenty se specifickými nároky zastř̌šuje centrum univerzitního sportu Fakulty sportovních studií (CUS FSpS). V současné době studuje na MU 90 studentů se zrakovým postižením, 86 studentů se sluchovým postižením, 95 studentů s pohybovým postižením a 178 studentů s dalšími specifickými nároky (vnitřní onemocnění, specifické poruchy učení aj.). Studenti se specifickými nároky mají stejně jako ostatní studenti MU povinnost splnit dva semestry tělesné výchovy v průběhu studia, mohou však žádat o zdravotní osvobození na základě doložené lékařské zprávy. Protože je však nabídka pohybových aktivit rozmanitá, studenti si obvykle některou z aktivit zvolí. Předměty nabízené studentům s postižením zahrnují např. plavání, horostěnu, tanec, tandemová kola, zdravotní tělesnou výchovu nebo futsal pro nevidomé (http://www. teiresias.muni.cz/).

Fakulta sportovních studií si kromě tradiční přípravy učitelů tělesné výchovy (a dalších neučitelských oborů) klade za cíl seznámit studenty s aplikovanými pohybovými aktivitami a možnostmi zapojení žáků se specifickými nároky do běžné výuky. Tělesná výchova je z tohoto pohledu předmět velmi specifický, vyžadující jistou míru motorických do- 
vedností a v praxi se bohužel často setkáváme se situací, kdy pedagog raději volí variantu takového žáka do praktické výuky nezapojit vůbec. Mnohdy je zde absence znalostí vhodných pohybových aktivit, jindy se může jednat o strach ze zranění žáka s postižením. Přitom však současné školní rámcové vzdělávací programy nabízí mnohem vyšší míru kreativity a inovace než tomu bylo v minulosti. Proto je studentům FSpS umožněno zvolit si některý z následujících předmětů, které tuto problematiku pokrývají a pomohou jim se na takové situace prripravit:

- Aplikovaná TV.

- Integrovaná speciálni pedagogika.

- Pohybová a tanečni terapie.

(Garantováno katedrou podpory zdraví a katedrou gymnastiky a úpoli̊.)

- Psychomotorika a Aplikovaná psychomotorika.

- TV-Alternativní pohybové aktivity a hry.

- Žonglování.

- Halliwickova metoda plavání.

(Garantováno Katedrou společenských věd ve sportu.)

Mimo univerzitní výuku jsou studenti FSpS zapojováni do dalších projektových aktivit, jako je spolupráce se specializovanými centry pro klienty se specifickými nároky. Pravidelně realizujeme pohybové lekce v Centru Kociánka, které poskytuje služby sociální péče a podporu dětem a mládeži s tělesným a druhotným mentálním postižením (http:// www.usp-kocianka.cz/). Studenti zde vystupují v roli asistentů a důraz je kladen nejen na samotné pohybové aktivity ale také zejména na komunikaci a přirozenou sociální interakci, jíž se klientům vzhledem $\mathrm{k}$ povaze postižení a následné sociální izolace často nedostává. Další z institucí, s nimiž lektoři a studenti FSpS spolupracují, je Parkinson Klub Brno, jehož posláním je napomáhat k posílení sebevědomí pacientů s Parkinsonovou chorobou, učit je překonávat každodenní problémy a tím ulehčovat složitou životní situaci (http://www.parkinson-brno.cz/). Pohybové aktivity u seniorů jsou odborníky všeobecně doporučovány. Jak např. 
udává kolektiv autorů Kolb et al (2009), pohybová hra u seniorů posiluje tělesné i duševní zdraví a rozvíjí rovněž pohybové kompetence. Pohybové lekce pro seniory (pod vedením lektorů z FSpS) jsou vždy uzpůsobeny jejich aktuálnímu zdravotnímu stavu, což však nebrání např́iklad tomu, aby rozvíjeli rovnováhové dovednosti pomocí chůze po laně, nataženém na zemi či si úspěšně osvojili základy žonglování se šátky či (Obr. 1).

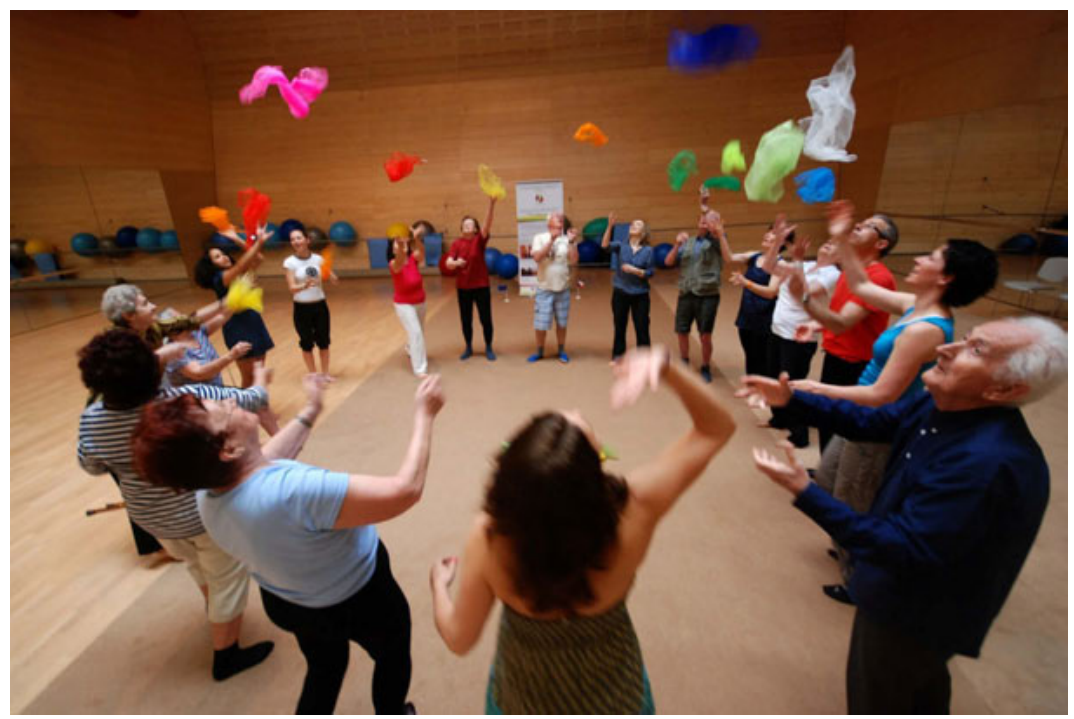

Obr. 1: Pohybová lekce pro seniory - Parkinsoniky

„Žonglování má mnoho pozitivních vlivů na člověka, z nichž některé jsou specifické pro tuto dovednost (reakční rychlost, jemná motorika) a jiné jsou přidružené, vyplývající z povahy pohybové aktivity (správné držení těla, balanční a rovnováhové schopnosti, prostorová orientace). Při žonglování podporujeme princip napětí a uvolnění, posilujeme zádové svalstvo a svaly horních končetin, rozvíjíme periferní vidění, vyrov- 
náme rozdíly mezi preferovanými končetinami - lateralita, pracujeme s vyrovnáváním nerovnovážných pozic“ (Trávníková, 2008). Protože jsou žonglérské aktivity snadno uzpůsobitelné pro různé věkové kategorie, jsou vhodnou alternativní pohybovou aktivitou i pro osoby se specifickými potřebami či seniory.

\section{Př́stupy k pohybovým aktivitám na vybraných českých institucích terciárního vzdělávání}

Jak již bylo řečeno, Fakulta sportovních studií MU navázala v rámci projektu spolupráci s několika českými a zahraničními institucemi, zabývajícími se a propagujícími aplikované pohybové aktivity. Jejich přístupy se liší vzhledem k zaměření studijních oborů i cílovým skupinám, s nimiž pracují.

\section{1) Ateliér VDN, Divadelní fakulta JAMU, Brno}

Ateliér Výchovné dramatiky Neslyšících je jedním z nejmladších oddělení Divadelní fakulty JAMU (založen r. 1992). Jedná se o umělecko-pedagogický studijní obor určený studentům se sluchovým postižením a dalším zájemcům. Základní složkou studijního plánu je předmět „pohybové divadlo“, přičemž důraz je kladen na individuální pohybovou a výtvarnou kreativitu studentů. Všechny získané dovednosti a znalosti uplatní studenti v pedagogické praxi při konkrétní a cílené práci s dětmi a mládeží. Přestože neslyšící studenti mají vlastní studijní program, žijí, studují a pracují v jedné budově společně se slyšícími studenty všech studijních oborů JAMU. Mají tak možnost využívat bohatě strukturovaný program divadelní fakulty (http://difa.jamu.cz/obory-a-ateliery/ atelier-vychovne-dramatiky-neslysicich.html).

$\mathrm{V}$ pohybových seminářích určených akademikům a studentům FSpS nabízí lektoři z Ateliéru VDN aktivity z oblasti pohybového divadla, jako je práce s gesty a mimikou či pantomimické hry. Mnohdy se seminářù účastní také studenti MU s postižením (sluchovým, tělesným), což je pro všechny zúčastněné strany prínosné z hlediska rozvoje nonverbální komunikace mezi slyšícími a Neslyšícími, či tvorby reprezenta- 
tivního znaku pro každého ze zúčastněných. Dalšími aktivitami, kterými se Ateliér VDN zabývá a nabízí v rámci projektové spolupráce, jsou základy partnerské akrobacie či tvořivá práce s rekvizitou.

\section{2) Katedra APA, Fakulta tělesné kultury, Univerzita Palackého, Olomouc}

Katedra Aplikovaných pohybových aktivit a přidružené Centrum APA jsou jedním z nejvýznamnějších center tohoto charakteru v ČR. Jejich aktivity pokrývají oblast vzdělávání cílových skupin a jednotlivců se specifickými nároky, školení pedagogů či možnosti zapůjčení speciálních kompenzačních pomůcek. Členové katedry jsou také aktivní na poli mezinárodní spolupráce $\mathrm{s}$ evropskou asociací APA, což byl jeden z impulzů k etablování České asociace APA (CAAPA, 2009). Hlavním obsahem pedagogické činnosti této katedry je zkvalitňování a rozvoj disciplín aplikovaných pohybových aktivit a speciálních didaktik TV a sportu pro občany se specifickými potřebami (děti a dospělí se zdravotním postižením, se sociálním znevýhodněním, senioři) a speciálně pedagogické disciplíny v garantovaných oborech (http://www.apa.upol.cz/). V seminářích určených studentům MU s postižením, studentům FSpS či oboru speciální pedagogika nabízí lektoři z Katedry APA zejména aktivity využívající kompenzační pomůcky a v českém prostředí již tradičně využívané aplikované pohybové aktivity (jako např. boccia pro osoby s tělesným postižením či showdown pro zrakově postižené, aj).

\section{3) Katedra speciální pedagogiky, Pedagogická fakulta, Univerzita} Hradec Králové

Za účelem sdílení a prohlubování znalostí problematiky a symptomů jednotlivých druhů postižení a specifických poruch jsme navázali úspěšnou spolupráci s akademiky z Katedry speciální pedagogiky UHK. Tato katedra garantuje obory Speciální pedagogika - vychovatelství a Speciálně pedagogická péče o osoby s poruchami komunikace (http://www.uhk.cz/). Výměnou za rozšíření povědomí o problematice osob s postižením jsme nabídli akademikům a studentům této katedry (potažmo i fakulty) praktické semináře s prvky psychomotorických a žonglérských her, modifikovaných pro potřeby jednotlivých postižení. 


\section{Př́ístupy k pohybovým aktivitám na vybraných zahraničních institucích terciárního vzdělávání}

Je zřejmé, že prrístup $\mathrm{k}$ alternativním pohybovým aktivitám osob se specifickými nároky se v každé kultuře mírně odlišuje. Proto probíhá projektová spolupráce také na poli mezinárodním, abychom tyto odlišnosti mohli zaznamenat a přenést do českého prostředí. Do projektu bylo na základě předchozí úspěšné spolupráce či dle zaměření vzdělávacích oborů přizváno několik zahraničních institucí a spolupráce je neustále rozšiřována.

\section{4) Faculty of Education, University of Ljubljana, Slovinsko}

Spolupráce s Pedagogickou fakultou univerzity v Ljubljaně je zakotvena na dlouholetých pracovních kontaktech akademiků FSpS a této zahraniční instituce zejména v oblasti Halliwickovy metody plavání. Povědomí o této velmi efektivní a vhodné metodě pro osoby s postižením, pocházející z Velké Británie není v České republice příliš velké a lektoři FSpS se proto snaží o její propagaci nejen ve výuce (samostatný předmět určený studentům FSpS). Při vzájemných konzultacích a seminářích jsme byli uvedeni do problematiky běžné praxe Halliwickovy metody a pravidelné práce s klienty a jejich rodinami. Spolupráce vyvrcholila praktickým seminářem pod vedením slovinských lektorů na půdě FSpS.

Cílem plavecké výuky podle Halliwickovy metody není směřovat k dokonalé plavecké technice. Přestože i zde je v pozdějších fázích výuky kladen důraz na správně prováděné plavecké pohyby podle individuálních možností plavce, stěžejní je snaha instruktorů a asistentů o to, aby se plavci ve vodě cítili dobře, prožívali radostné pocity, vytvářeli si a upevňovali kladný vztah k vodě (AST, 1995). Halliwickova metoda plavání využívá základní principy, jako jsou „one to one“, „face to face“ či absence nadnášecích pomůcek.

\section{5) Interkantonale Hochschule für Heilpädagogik, Zurich, Švý- carsko}

HfH jakožto Univerzita aplikovaných věd speciální pedagogiky nabízí studijní programy školní a předškolní speciální pedagogiky, řečové 
terapie, tlumočení do znakového jazyka a psychomotorické terapie (http:// www.hfh.ch/). V oblasti psychomotoriky je zde zřejmé terapeutické zaměření této disciplíny, přičemž absolventi mohou působit jako psychomotoričtí odborníci - terapeuti - ve školách či specializovaných pracovištích. Psychomotorika na FSpS, potažmo v českém prostředí, sleduje linii psychomotoriky jako „výchovy pohybem“ (Blahutková et al, 2005), podobně jako v Německu, Holandsku a dalších státech. Na rozdíl od švýcarského individuálního př́stupu „terapeut-dítě“, je psychomotorika u nás realizována ve větších kolektivech, obvykle formou skupinového cvičení $v$ tělocvičně a je zaměřena na aktivní pohybový prožitek. Je tedy velmi zajímavé sledovat odlišnosti v obou př́stupech a přitom vidět $\mathrm{v}$ pozadí shodný cíl, tedy rozvoj kompetencí a dovedností dítěte případně zaměření na konkrétní specifické oblasti a odstranění problematických jevů. Je zřejmé, že při individuálním př́stupu má psychomotorický terapeut možnost proniknout pod povrch problému a cíleně působit na dítě. $\mathrm{Na}$ druhou stranu je zde absence sociální interakce s vrstevníky, což při „hře“ " představuje velmi důležitý aspekt. Akademici z HfH realizovali na půdě FSpS během své stáže v květnu 2013 několik seminářu a konzultací, zaměřených na grafomotoriku dětí, taneční terapii či psychomotorickou terapii.

Do subjektů zahraniční spolupráce byla dále zařazena Pedagogická fakulta Univerzity Regensburg (Německo), která se mimo tradičních tělovýchovných směrů zaměřuje také na výzkum žonglování a prostorové orientace či laterality. Lektoři německá organizace Acroyogy představili na půdě FSpS pohybová cvičení z oblasti partnerské akrobacie a „terapeutického létáni'“(Obr. 2), která jsme následně úspěšně aplikovali do výuky s neslyšícími studenty MU a Difa JAMU. Další spolupráce je plánována s univerzitou Helsinki Metropolia University of Applied Sciences, která využivá psychomotorické aktivity rovněž jako formu aplikované pohybové aktivity pro specifické cílové skupiny. 


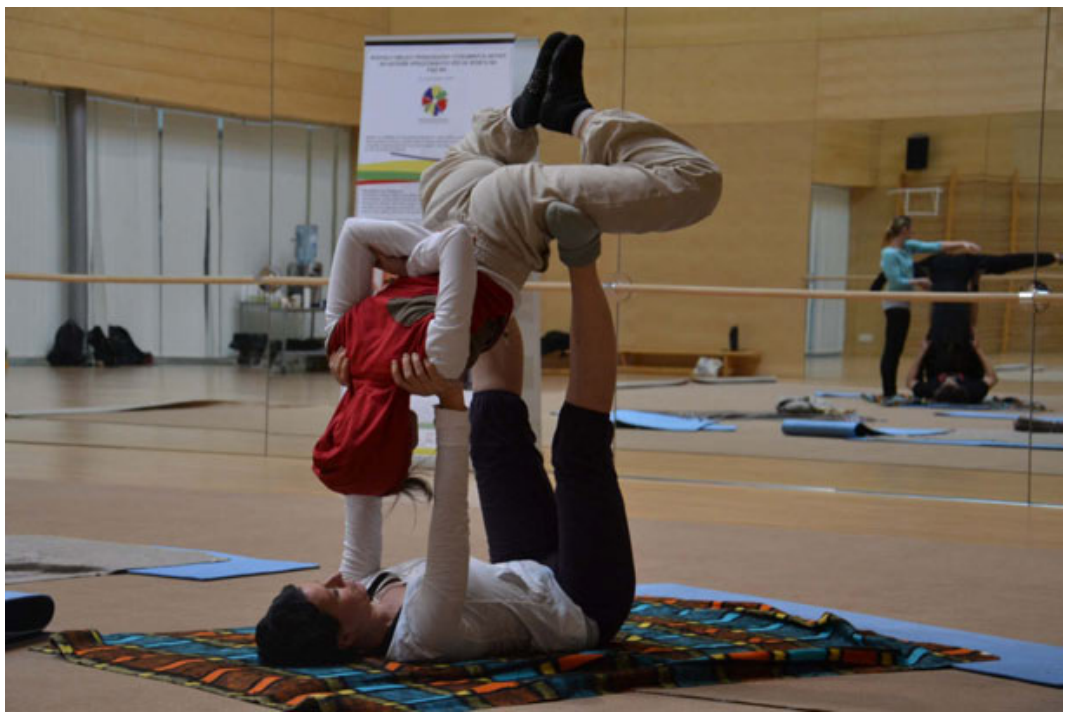

Obr. 2: Terapeutické létaní, jedna ze složek oboru Acroyoga

\section{ZÁVĚR}

Jak vyplývá z výstupů jednotlivých úspěšných spoluprací řešitelského týmu Fakulty sportovních studií s českými a zahraničními institucemi terciárního vzdělávání, alternativní pohybové aktivity jsou již pevně zakotveny ve vzdělávacích a studijních programech. Mnoho výše zmíněných subjektů také uplatňuje modifikované - aplikované pohybové aktivity v praxi s klienty s různým typem postižení. Domníváme se, že tento přístup napomůže úspěšnější integraci osob se specifickými nároky do společnosti, právě včetně mnohdy problematicky nahlížených pohybově sportovních aktivit. Zásadním aspektem úspěšné integrace je komunikace, přičemž obtíže s komunikací velmi často patří mezi symptomy jednotlivých druhů postižení. Slowík (2010) uvádí, že pokud založíme př́stup integrace a inkluze osob se specifickými nároky do běžné společnosti na myšlence, že ,být odlišný je normální“, neměly by se 
odlišnosti a obtíže v komunikaci stávat příčinou sociálního vyloučení, či izolace znevýhodněných jedinců, ale spíše výzvou k pochopení jejich situace a hledání vhodných způsobů dorozumívání.

Pokud se daří uplatňovat integraci osob se specifickými nároky do pohybových aktivitna úrovni terciárního vzdělávání, jsme přesvědčeni, že stejného efektu mohou dosáhnout i pedagogičtí pracovníci, vychovatelé, trenéři či samotná rodina dané osoby s ohledem na její individuální potřeby a aktuální zdravotní stav v různých věkových kategoriích.

\section{LITERATURA}

AST. (1995). The Halliwick Method: Basic Course, Handbook. Association of Swimming Therapy.

Blahutková, M., Klenková, J., Zichová, D. (2005). Psychomotorické hry pro děti s poruchami pozornosti a pro hyperaktivní děti. Brno: MU.

Kolb, M., Kolb, B., Steininger Ch. (2009). Spielen im Herz- und Alterssport. Aachen: Meyer und Meyer Verlag.

Slowík, J. (2010). Komunikace s lidmi s postižením. Praha: Portál.

Trávníková, D. (2008). Žonglování. Brno: FspS, MU.

Válková, H. (2012). Teorie aplikovaných pohybových aktivit pro užití v praxi I. Olomouc: UP v Olomouci, KTV.

\section{INTERNETOVÉ ZDROJE:}

http://www.apa.upol.cz/

http://www.caapa.cz/

http://difa.jamu.cz/obory-a-ateliery/atelier-vychovne-dramatiky-neslysicich.html http://www.hfh.ch/

http://www.parkinson-brno.cz/

http://www.teiresias.muni.cz/

http://www.uhk.cz/

http://www.usp-kocianka.cz/

\section{KONTAKT:}

Mgr. Dagmar Trávníková, Ph.D.; travnikova@fsps.muni.cz 